\section{Embryo researcher is sanctioned for using NIH resources}

[WASHINGTON] The US National Institutes of Health (NIH) confirmed last week that it has cut all research links with a leading reproductive biologist for breaching a ban on the use of federal funds for research on human embryos.

According to Anne Thomas, spokeswoman for NIH director Harold Varmus, the biomedical agency ended a contract with Mark Hughes, director of Georgetown University's Institute for Molecular and Human Genetics in Washington DC, last October.

"What concerned us was that [Hughes] used NIH equipment and government-funded research fellows to do pre-implantation diagnosis," says Thomas. This was despite the fact that he had been told that NIH resources could not be used in this manner.

Hughes had been working at the National Center for Human Genome Research (NCHGR) under a contract arrangement by which part of his salary was paid by Georgetown with funding received from NIH.

The work that caused concern was not conducted at NCHGR, where Hughes, an expert in single-cell biology, was doing experiments that included creating cDNA libraries from a single cell. Thomas says one or more postdoctoral fellows complained to NCHGR officials about separate research on which Hughes had asked them to collaborate at the Montgomery Fertility Institute, a private practice at Suburban Hospital, near NIH in Bethesda, Maryland.

Hughes had been conducting preimplantation diagnosis on test-tube embryos at the private institute, removing a single cell at the eight-cell stage to screen for genetic abnormalities and implanting the remaining seven cells if none was found.

The work is not illegal, and is done privately in the United States, the United Kingdom and elsewhere. But Congress banned federal funding for human embryo research in 1996, and renewed the ban for the fiscal year 1997, which ends on 30 September.

Neither Hughes, Georgetown University nor NCHGR officials were available for comment this week. Earlier, Hughes told The Washington Post that "there has never been any intention of doing anything wrong". The newspaper said that he regretted having used government resources at the private clinic, but made no apologies for the work itself.

In the past, Hughes has opposed the federal ban (see Nature 376, 288; 1995). He was a member of an expert NIH panel which in 1994 concluded that human embryo research was acceptable - within strict constraints - before the primitive streak appears, at day 14 . Meredith Wadman

\title{
Russian space module in need of more protection'
}

[WASHINGTON] Russian-built sections of the international space station will have to be fitted with extra shielding to protect against damage from orbital debris, says a report published last week by the US National Research Council (NRC).

The NRC, the operational arm of the National Academy of Sciences, says that the station may receive warnings about possible collisions with large objects more often than previously thought - ten times a year instead of six times. But it adds that the National Aeronautics and Space Administration (NASA) and its European, Japanese and Canadian partners have a sensible plan to counter the threat from debris.

Shields on the station's outer surfaces will pulverize small objects that strike the station at high speed. But Russian components under construction - particularly a 'service module' that will house the initial crew of three - have not been shielded to the same standard as other sections of the station.

The risk is not that the pressurized module would be penetrated by debris - the walls are thick enough to prevent that - but that plumbing and other exposed hardware on the outside would be damaged, according to Nicholas Johnson of the NASA Johnson Space Center. He was originally a member of the NRC panel, but resigned earlier this year when he took a job as NASA's expert on space debris.

Even before the NRC report appeared, US and Russian engineers had a solution in mind. Spacewalking astronauts could fit the Russian components with additional shielding after the hardware is delivered to orbit.

Installing the shielding before launch is ruled out by the way the module fits on top of its booster rocket, says Johnson. But the proposed strategy has the advantage of deferring any expense associated with shielding to later in the programme.

Russian engineers have tended to play down the threat from debris, pointing out the lack of serious problems in their decades of experience with small space stations. Johnson agrees that NASA errs on the side of caution: "We have placed high standards on the space station in terms of reliability."

Objects larger than $10 \mathrm{~cm}$ in diameter could cause serious damage if they hit even shielded parts of the station, so the strategy for them is different: get out of the way. US military surveillance cameras that track orbiting junk would issue a warning whenever an object was about to come too close to the station, and the entire structure would be moved.

Such warnings have been issued in the past for the US space shuttle, and recently the Americans began providing the same service to the Russian Mir space station. The shuttle has been moved out of the way to avoid a collision, but Russian space officials have so far chosen not to move Mir on the few occasions it has been warned, trusting in the very long odds against a collision.

Even if the number of warnings does increase from six to ten a year - as the NRC report suggests that it might, on the basis of recent predictive models - international space station managers would also be free to ignore a warning. They might do so if some delicate, ultra-quiet microgravity experiment would be jeopardized by firing the station's manoeuvring engines. Tony Reichhardt

\section{Cassini gets golden gown made to measure}

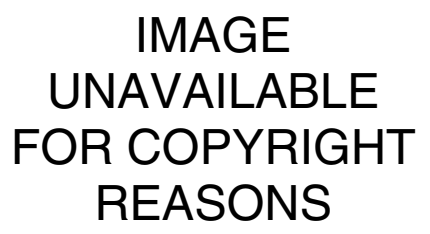

[LONDON]. The art of bespoke tailoring was called upon last month to cut, stitch and fit a shiny, gold-coloured protective suit for the Cassini spacecraft, due to begin a seven-year voyage to Saturn in October.

Technicians and engineers working for the NASA used traditional industrial sewing machines, brown paper patterns and large cutting tables to make the thermal blankets to protect Cassini from the extreme temperatures of deep space.

Mark Duran, supervisor of NASA's 'shield shop', which provides survival gear for spacecraft and instruments, says that Cassini's super-strong and extremely lightweight blankets "are built unlike any others". They are designed to withstand temperatures from -220 to $+250^{\circ} \mathrm{C}$. 